gặp nhất là: đau đầu đột ngột $(98,61 \%)$, buồn nồn và nôn $(58,33 \%)$. Có $81,94 \%$ các bệnh nhân có hội chứng màng não, $25 \%$ có suy giảm tri giác, và $9,72 \%$ có dấu hiệu thần kinh khu trú. $66,67 \%$ có độ lâm sàng là $\mathrm{I}, 23,61 \%$ độ II, và 9,72\% độ III

Đặc điểm cận lâm sàng: 8,33\% có chảy máu dưới màng nhện Fisher độ $1,19,44 \%$ độ 2 , và $72,22 \%$ độ 3 . Túi phình động mạch thông trước gặp nhiêu nhất 48,61\%, sau đó là động mạch thông sau 30,56\%, và động mạch não giữa $16,67 \%$.

Chỉ định phẫu thuật: với các trường hợp có độ lâm sàng từ I-III, và chảy máu dưới màng nhện từ độ 1-3, và kích thước túi phình $\leq 10 \mathrm{~mm}$.

\section{TÀI LIÊU THAM KHẢO}

1. Nguyễn Thế Hào ${ }_{k}$ (2006), "Nghiên cứu chẩn đoán và điều trị phâuu thuâtt chảy máu dưới màng nhện do vỡ túi phình hệ động mạch cảnh trong", Luận ấn Tiến sĩ Y học, Đại học Y Hà Nội.

2. Nguyến Thế Hào, Phạm Quỳnh Trang, Trân Trung Kiên, (2017), "Nghiên cứu hiệu quả và tính oan toàn của phâuu thuât ít xâm lấn trong điều trị túi phình động mạch não vỡ", Y học Thành Phố Hồ Chì Minh, tập 21(6): 137-141.
3. Alessandro C., Emanuele P., Roberto D.B., et al. (2013), "Clinical presentation of cerebral aneurysms.", European Journal of Radiology, 82: 1618-1622.

4. Fischer G., Stadie A., Reisch R., et al. (2011), "The Keyhole Concept in Aneurysm Surgery: Results of the Past 20 Years.", Operative Neurosurgery 1, 68: 45-51.

5. Lan Q., Gong Z., Kang D., et al, (2006), "Microsurgical experience with keyhole operations on intracranial aneurysms", Surg Neurol, 66(S1): 2-9.

6. Perneczky A., Reisch R. (2008), "Keyhole approaches in Neurosurgery: Concept and surgical technique". Spinger Wien NewYork.

7. Saberi H., Hashemi M., Habibi Z., et al. (2011), "Diagnostic Accuracy of Early Computed Tomographic Angiography for Visualizing Medium Sized Inferior and Posterior Projecting Carotid System Aneurysms.", Iran J Radiol, 8(3): 139-144.

8. Wang H., Luo L., Ye Z., et al. (2015), "Clipping of anterior communicating artery aneurysms in the early post-rupture stage via transorbital keyhole approach - Chinese neurosurgical experience.", British Journal of Neurosurgery, Early Online, 1-6.

9. Yamahata H., Tokimura H., Tajitsu K., et al. (2014), "Efficacy and safety of the pterional keyhole approach for the treatment of anterior circulation aneurysms", Neurosurg Rev., 37: 629-636.

\title{
ĐẶC ĐIỂM LÂM SÀNG, CÂ̂N LÂM SÀNG VIÊM PHẾ QUẢN PHỔI NHIỄM RSV (Respiratory Syncytial Virus) Ở TRẺ EM TẠI BỆNH VIÊ̂N SẢN NHI VĨNH PHÚC
}

\section{TÓM TẮT}

Viêm phế quản phổi (VPQP) là bệnh lý thường gặp và là nguyên nhân chính gây tử vong ở trẻ em. Virus là nguyên nhân hàng đầu gây viêm phế quản phổi ở trẻ em, trong đó virus hợp bào hô hấp (RSV) là nguyên nhân thường gặp nhất. Mục tiêu: Mô tả một số đặc điểm lâm sàng, cân lâm sằng của bệnh nhần viêm phế quản phổi có nhiếm RSV dưới 5 tuối tại Bệnh viên Sản Nhi Vinh Phúc. Đối tướng nghiên cứu: 206 bệnh nhân dưới 5 tuổi viêm phế quản phổi có nhiễm RSV trong thời gian từ $01 / 6 / 2020$ đến $31 / 05 / 2021$. Phương pháp nghiên cứu: tiến cứu, mô tả cắt ngang. Kết quả: VPQP nhiểm RSV chú yếu gặp ở nhóm tuổi < 12 tháng tuổi $(91,2 \%)$. Các triệu chứng lâm sàng thường gặp là ho, chảy mũi, khò khè, thở nhanh, rút lõm lồng ngực đều chiếm tỷ lệ cao (> 80\%). 98,5\% bệnh nhân nghe phổi có rale. Hầu hết

\footnotetext{
${ }^{1}$ Bênh viện Sản Nhi Vĩnh Phúc.

${ }^{2}$ Trường Đai hoc Y Hà Nôi.

Chịu trách nhiệm chính: Hoàng Trung Thanh

Email: thanhnhivp@gmail.com

Ngày nhận bài: 10.6.2021

Ngày phản biên khoa học: 30.7.2021

Ngày duyệt bài: 11.8.2021
}

bệnh nhân có số lượng bạch câu và CRP bình thường. 90,3\% bênh nhân có hình ảnh tổn thương phổi trên phim Xquang phổi. Trong nghiên cứu của chúng tôi, có đến $51,5 \%$ bệnh nhân đủ tiêu chuẩn chẩn đoán VPQP nặng điều này cũng phù hợp với tỷ lệ trẻ < 2 tháng trong nghiên cứu chiếm tỷ lệ cao. Kết luân: RSV hay gặp gây viêm phế quản phổi ở trẻ < 12 tháng tuổi. Triệu chứng hay gặp là ho, chảy mũi, khò khè, thở nhanh, rút lõm lồng ngực. Số lượng bạch câu và CRP thường bình thường.

Tư khóa: Viêm phể quản phổi, virus hợp bào hô hấp, RSV.

\section{SUMMARY \\ SOME CLINICAL AND SUBCLINICAL CHARACTERISTICS OF RSV-INFECTED PNEUMONIA PATIENTS AT VINH PHUC OBSTETRICS AND CHILDREN'S HOSPITAL \\ Pneumonia is a common disease and life- threatening disease in pediatrics. Virus is an important cause of pneumonia in children, of which Respiratory syncytial virus (RSV) is the most common cause. Objectives: Describe some clinical and subclinical characteristics of RSV-infected pneumonia patients under 5 years old at Vinh Phuc Obstetrics and Children's Hospital. Study subjects: 206 patients}


under 5 years old suffering from pneumonia caused by RSV from June 2020 to May 2021. Research method: prospective multiside, cross-sectional description. Results: The prevalence of RSV is in the age group < 12 months old $(91.2 \%)$. Common clinical symptoms are cough, runny nose, wheezing, tachypnea, and chest indrawing (> 80\%). 98.5\% patients has rales in lung. Most patients have normal white blood cell counts and CRP. $90.3 \%$ of patients have lung lesions on chest X-ray. Conclusion: RSV is the common cause of pneumonia in children $<12$ months old. Common symptoms are cough, runny nose, wheezing, rapid breathing, chest indrawing. white blood cell counts and CRP are usually normal. $51,5 \%$ of patients are severe pneumonia which is consistent with the high rate of children $<2$ months in the study.

Keywords: pneumonia, Respiratory syncytial virus, RSV.

\section{I. ĐĂT VẤN ĐỀ}

Viêm phổi là bệnh thường gặp ở trẻ em và là một trong những nguyên nhân chính gây tử vong ở trẻ em [1]. Virus hợp bào hô hấp (RSV) là căn nguyên thường gặp gây nhiễm khuẩn hô hấp cấp nói chung và VPQP nói riêng. Theo nghiên cứu của Nair $\mathrm{H}$ và cộng sự, ước tính có khoảng 33,8 triệu trường hợp nhiễm trùng đường hô hấp dưới do nhiễm RSV xảy ra trên toàn thế giới ở trẻ dưới 5 tuổi, với ít nhất 3,4 triệu trẻ bị nhiễm trùng đường hô hấp dưới cần phải nhập viện điều trị và có khoảng 66000 199000 trẻ dưới 5 tuổi chết vì nhiễm trùng đường hô hấp dưới do nhiễm RSV [2]. Việc nghiên cứu và cập nhật dịch tễ học lâm sàng viêm phế quản phổi do virus RSV tại các bệnh viện, các địa phương là vô cùng quan trọng trong chiến lược kiểm soát, quản lý bệnh lý đường hô hấp cấp ở trẻ em. Xuất phát từ thực tiễn tai bênh viên Sản Nhi Vĩnh Phúc chưa có nghiên cứu nào về viêm phế quản phổi có nhiễm RSV, chúng tôi tiến hành nghiên cứu này với mục tiêu: "Mô tả một số đặc điểm lâm sàng, cận lầm sàng của bênh nhân viêm phế quản phố có nhiếm RSV dưới 5 tuổi tại Bệnh viện Sản Nhi Vinh Phúc".

\section{II. ĐỐI TƯợNG VÀ PHƯƠNG PHÁP NGHIÊN CỨU}

1. Đối tượng nghiên cứu. Tất cả các bệnh nhân dưới 5 tuổi nhập viện tại Bệnh viện Sản nhi Vĩnh Phúc được chẩn đoán Viêm phế quản phổi và có nhiễm RSV trong thời gian từ 01/06/2020 31/05/2021.

Tiêu chuẩn chẩn đoán: Tiêu chuẩn viêm phổi theo Bộ Y tế (2014) [3]: Ho, sốt kèm theo ít nhất một trong các dấu hiệu: thở nhanh, rút lõm lồng ngực, nghe phổi thấy bất thường (giảm thông khí, ran ẩm to, nhỏ hạt, có thể kèm ran rít, ran ngáy...). X- quang tim phổi có hình ảnh tổn thương phổi.

Chẩn đoán viêm phổi nặng khi trẻ có dấu hiệu của viêm phổi kèm theo ít nhất một trong các dấu hiệu:

+ Dấu hiệu nặng toàn thân: bỏ bú hoặc không uống được, rối loạn tri giác như lơ mơ hoặc hôn mê, co giật

+ Dấu hiệu suy hô hấp nặng

+ Tím tái hoăc $\mathrm{SpO} 2<90 \%$

+ Trẻ $<2$ tháng

Tiêu chuẩn chẩn đoán có nhiễm RSV: Xét nghiệm tìm RSV bằng phương pháp Quick test.

\section{Phương pháp nghiên cứu}

Thiết kế nghiên cứu: tiến cứu, mô tả cắt ngang.

Phương pháp: Bệnh nhân đủ tiêu chuẩn nghiên cứu được hỏi bệnh, khám lâm sàng theo mẫu bệnh án nghiên cứu có sẵn để phát hiện các triệu chứng cơ năng và thực thể của bệnh nhân. Lãy máu xét nghiệm công thức máu và CRP tại thời điểm nhập viện, đồng thời lấy dịch ty. hầu làm test nhanh RSV.

Xử lý số liệu: bằng phần mềm thống kê y hoc SPSS 22.0.

\section{KẾT QUẢ NGHIÊN CứU}

Trong thời gian từ 01/06/2020 đến 31/05/2021 có 206 bệnh nhân đủ tiêu chuẩn chẩn đoán VPQP có nhiễm RSV được đưa vào nghiên cứu.

Bảng 1. Đặc điểm chung của đôi tượng nghiên cứu $(n=206)$

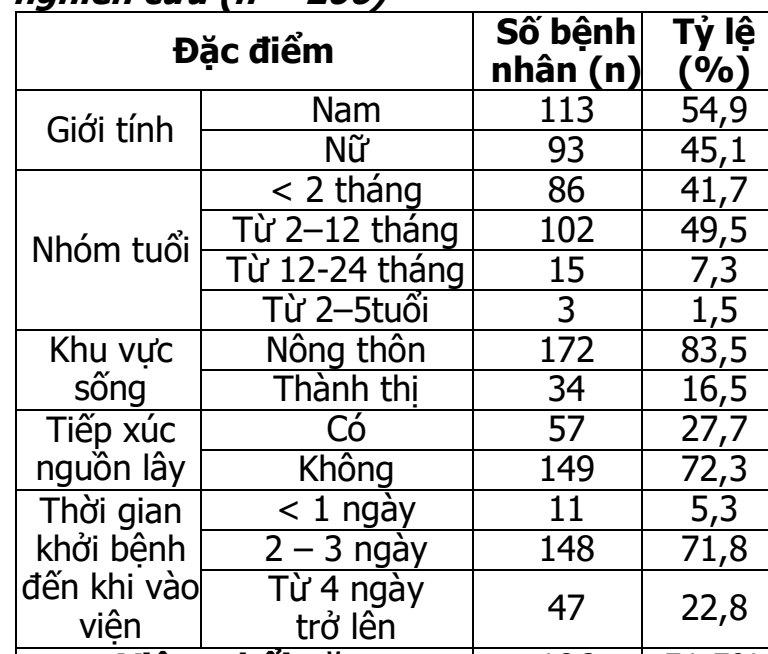

Viêm phối nặng

$106 \quad 51,5 \%$

Nhận xét: VPQP nhiếm RSV gặp chủ yếu ở nhóm trẻ < 12 tháng $(91,2 \%)$ và tập trung ở vùng nông thôn. Tỷ lệ nam: nữ $=122: 1$. Tỷ lệ những ca xác nhận có nguồn lây nhiếm là thấp $(27,2 \%)$. Thời gian từ khi khởi phát bệnh đến khi 
vào viện là từ $1-10$ ngày, trung bình là $2,9 \pm$ 1,3 ngày, trong đó trẻ được đi khám chủ yếu sau $2-3$ ngày kể từ khi khởi phát bệnh $(71,8 \%)$.

Bảng 2. Triệu chứng cơ năng ở trẻ VPQP nhiếm RSV $(n=206)$

\begin{tabular}{|c|c|c|}
\hline Triệu chứng & $\begin{array}{c}\text { Số bệnh } \\
\text { nhân }(\mathbf{n})\end{array}$ & Tỷ lệ $\mathbf{( \% )}$ \\
\hline Chảy mũi & 162 & 78,6 \\
\hline Ho & 205 & 99,5 \\
\hline Khò khè & 179 & 86,9 \\
\hline Khó thở & 172 & 83,5 \\
\hline Sốt & 79 & 38,3 \\
\hline
\end{tabular}

Nhận xét: Những triệu chứng cơ năng thường gă̆p nhất ở VPQP nhiễm RSV là ho, khò khè, khó thở (> 80\%). Triệu chứng sốt chỉ chiếm số ít (38,3\%).

\begin{tabular}{|c|c|c|}
\hline Triệu chứng & $\begin{array}{c}\text { Số bệnh } \\
\text { nhân }\end{array}$ & $\begin{array}{c}\text { Tỷ lệ } \\
(\mathbf{\%})\end{array}$ \\
\hline Thở nhanh & 172 & 83,5 \\
\hline Phập phồng cánh mũi & 33 & 16 \\
\hline Rút lõm lồng ngực & 165 & 80,1 \\
\hline Tím tái & 37 & 18 \\
\hline Thở rên & 14 & 6,8 \\
\hline Ran bệnh lý tại phối & 203 & 98,5 \\
\hline
\end{tabular}

Nhận xét: Các triệu chứng thực thế thường găp nhất ở VPQP nhiễm RSV là thở nhanh $(83,5 \%)$ và rút lỗm lî̀ng ngực $(80,1 \%) .98,5 \%$ bệnh nhân trong nghiên cứu có tiếng rale bệnh lý, trong đó chủ yểu là rale ẩm $(97,6 \%)$ và rale rít (42,7\%).

Bảng 4. Đặc điểm cận lâm sàng của bệnh nhân khỉ vào viện ( $n=206)$

\begin{tabular}{|c|c|c|c|}
\hline \multicolumn{2}{|c|}{ Cận lâm sàng } & $\begin{array}{c}\text { Số bệnh } \\
\text { nhân (n) }\end{array}$ & $\begin{array}{c}\text { Tỷ lệ } \\
(\%)\end{array}$ \\
\hline \multirow{2}{*}{$\begin{array}{c}\text { Bạch } \\
\text { cầu }\end{array}$} & $\begin{array}{c}\text { Bình thường } \\
(\leq 10 \mathrm{G} / \mathrm{L})\end{array}$ & 113 & 54,9 \\
\cline { 2 - 4 } & Tăng $(>10 \mathrm{G} / \mathrm{L})$ & 93 & 45,1 \\
\hline \multirow{2}{*}{ CRP } & $\begin{array}{c}\text { Bình thường } \\
(<6 \mathrm{mg} / \mathrm{l})\end{array}$ & 154 & 74,8 \\
\cline { 2 - 4 } & Tăng $(\geq 6 \mathrm{mg} / \mathrm{l})$ & 52 & 25,2 \\
\hline \multirow{2}{*}{$\begin{array}{c}\text { Xquang } \\
\text { phổi }\end{array}$} & Bình thương & 20 & 9,7 \\
\cline { 2 - 4 } & Có tốn thương & 186 & 90,3 \\
\hline
\end{tabular}

Nhân xét: $54,9 \%$ bệnh nhân có số lượng bạch cẩu bình thường, $74,8 \%$ bệnh nhân có CRP bình thường. $90,3 \%$ bệnh nhân có hình ảnh tổn thương trên phim Xquang

\section{BÀN LUẬN}

VPQP do RSV xảy ra chủ yếu ở nhóm trẻ $<12$ tháng $(91,2 \%)$, trong đó riêng nhóm trẻ $<2$ tháng tuổi đã chiếm tới $41,7 \%$ ở cả 2 giới. Kết quả này tương đồng với nghiên cứu của tác giả Trần Đình Nguyên và cộng sự năm 2013 cũng cho thấy tỷ lệ viêm đường hổ hấp cấp do RSV chủ yếu ở nhóm trẻ < 12 tháng tuổi $(69,3 \%)$ và tỷ lệ nam: nữ = 1,7:1 [4]. Tác giả Nokes D] và cộng sự (2009) nghiên cứu trên 25149 trẻ viêm phổi do RSV cũng cho thây 79,8\% thuộc nhóm < 12 tháng tuổi và tỷ lệ nam: nữ $=1,3 \cdot[5]$. Trong nghiên cứu của chúng tôi, có đến $51,5 \%$ bệnh nhân đủ tiêu chuẩn chẩn đoán VPQP nặng điều này cũng phù hợp với tỷ lệ trẻ $<2$ tháng trong nghiên cứu chiếm tỷ lệ cao.

Thời gian kể từ khi bắt đầu có triệu chứng đến khi trẻ được đi khám là là $2,9 \pm 1,3$ ngày, phù hợp với sinh bệnh học của viêm đường hô hấp do RSV thường có triệu chứng rõ ràng và nặng hơn từ ngày thứ $2-4$.

Các triệu chứng lâm sàng là các triệu chứng điển hình của viêm phổi, trong đó triệu chứng ho, khò khè, thở nhanh và rút lõm lồng ngực chiếm tỷ lệ cao (>80\%). Tác giả Trần Đình Nguyên và Nokes DJ cũng có những triệu chứng lâm sàng thường gặp giống với nghiên cứu của chúng tôi $[4,5]$. Hầu hết bệnh nhân trong nghiên cứu của chúng tôi khi khám phổi đều có rale bệnh lý $(98,5 \%)$, chủ yếu là rale ẩm, rale rít. Điều này khá tương đồng với tác giả Lê Thị Hồng Hanh (2020) với 96,8\% có rale ở phổi.

Chỉ số nhiễm trùng gồm số lượng $\mathrm{BC}$ và $\mathrm{CRP}$ thường không tăng cao trong tại thời điểm trẻ nhập viện, phù hợp với cơ chế bệnh sinh do virus gây ra. Tuy nhiên, có $45,1 \%$ bệnh nhân có tăng số lượng bạch cầu nhưng chủ yếu là tăng nhẹ và 25,2\% bệnh nhân tăng CRP nguyên nhân có thể do bội nhiễm hoặc đồng nhiễm vi khuẩn hay có các nhiễm trùng khác kèm theo. Nghiên cứu của giả Lê Thị Hồng Hanh (2020) ở 250 trẻ VPQP nặng nhiễm RSV cũng cho kết quả tương tự [6].

Hầu hết bệnh nhân của chúng tôi có hình ảnh tổn thương trên phim Xquang như tổn thương nhu mô, khoảng kẽ, ứ khí hoặc xẹp phổi. Nghiên cứu của W Guo và cộng sự năm 2012 cũng chỉ ra những tổn thương đa dạng ở bệnh nhân viêm phế quản phổi nhiềm RSV gồm tổn thương mờ 2 bên phổi $(63,3 \%)$, tổn thương dạng kẽ $(15,7 \%)$, dạng thùy $(7,1 \%)$, ứ khí $(13,8 \%)[7]$.

\section{KẾT LUÂN}

VPQP nhiễm RSV chủ yếu gặp ở nhóm tuổi < 12 tháng tuổi (91,2\%), tỷ lệ nam: nữ là 1,2:1. Các triệu chứng lâm sàng hay gặp là ho, chảy mũi, khò khè, thở nhanh, rút lõm lồng ngực đều chiếm tỷ lệ cao (>80\%). Số lượng $\mathrm{BC}$ và $\mathrm{CRP}$ thường không tăng cao tại thời điểm trẻ nhập viện.

\section{TÀI LIẸU THAM KHẢO}

1. Simoes EAF, et al (2006). Acute Respiratory Infections in Children. In: Jamison DT, Breman JG, Measham AR, et al., editors. Disease Control 
Priorities in Developing Countries. 2nd edition. Washington (DC): The International Bank for Reconstruction and Development / The World Bank. Chapter 25

2. Nair $\mathbf{H}$ et al (2010). Global burden of acute lower respiratory infections due to respiratory syncytial virus in young chil-dren: a systematic review and meta analysis. Lancet, 375, pp.1545 - 1555.

3. Quyết định số 101/QĐ-BYT ngày 09 tháng 01 năm 2014 Bộ Y Tế. Hướng dẫn xử trí viêm phổi cộng đồng ở tré em.

4. Tran DN, Pham TMH, Ha MT et al (2013). Molecular epidemiology and disease severity of human respiratory syncytial virus in Vietnam. PLoS One, 8(1), e45436.

5. Nokes DJ et al (2009). Incidence and Severity of Respiratory Syncytial Virus Pneumonia in Rural Kenyan Children Identified through Hospital Surveillance. Clinical Infectious Diseases, 49, 1341 - 1349.

6. Lê Thi Hồng Hanh. Đắc điểm dich tê̂ hoc lầm sàng ở trẻ viêm phổi nặng có nhiếm RSV tại Trung tâm Hô hấp Bệnh viện Nhi Trung ương. Tạp chí nghiên cứu và thực hành Nhi khoa. 2020; 4 (5): 1-9.

7. Guo $W$, Wang J, Sheng $M$ et al (2012). Radiological findings in 210 paediatric patients with viral pneumonia: a retrospective case study. $\mathrm{Br}$ J Radiol; 85(1018):1385-1389.

\section{ĐÁNH GIÁ HIỂU BIẾT VÀ SỰ HÀI LÒNG CỦA NGƯờI BỆNH VỀ VIỆC CUNG CẤP THÔNG TIN CẦN THIẾT TRƯớC MỔ ở NGƯờI BỆNH PHẪU THUẬT TÁI TẠO DÂY CHẰNG CHÉO TRƯớC TẠI BỆNH VIỆN ĐẠI HỌC Y HÀ NộI}

\section{TÓM TẮT}

Mục tiêu: Đánh giá hiểu biết và sự hài lòng của người bệnh về những thông tin cần thiết trước mổ ở người bểnh mổ nội soi tái tạo dây chằng chéo trước khớp gối tại Bệnh viện Đai học Y Hà Nội. Đối tượng và phương pháp nghiên cứu: Phỏng vấn ngâuu nhiên 86 người bênh mổ nôi soi tái tao dây chẳng chéo trước khớp gối tại Bệnh viện Đại học Y Hà Nội trong thời gian từ tháng 6 năm 2019 đến hết tháng 12 năm 2020 theo một bộ câu hỏi được thiết kế để đánh giá hiểu biết và sự hà̉i lòng của người bênh về viêc cung cấp những thông tin cần thiết trước mổ tại thời điểm trước khi đi mổ. Kết quả nghiên cứu: Thây thuốc có xu hướng cung cấp nhiều thông tin về chẩn đoán bênh, tổn thương giải phấu của khớp gối, lý do phải mổ, can thiệp của bác sĩ trong mổ, các biến chứng chính sau mổ, khả năng thành công của ca mổ so với các thông tin về cảm giác của người bênh sau mổ, đau và kiểm soát đau sau mổ, thời gian cần nghỉ việc sau mổ và các lưu ý trong sinh hoạt sau mổ. Người bệnh chưa hài lòng với việc cung cấp các thông tin cân thiết trước mổ tái tạo dây chẳng chéo trước. Kết luận: Quá trình cung cấp thông tin cần thiết trước mổ của thầy thuốc cho người bểnh tái tao dây chằng chéo trước cân được thực hiện hiệu quả hơn để người bênh thực sự chia sẻ quyết đđịnh điêu trị và hài lòng với quá trình cung cấp thông tin đó.

Tư khóa: đồng thuân dưa trên sự hiểu biết; nôi soi khớp gối; tái tạo dây chằng chéo trước; Đại học Y Hà Nội

${ }^{1}$ Trường Đại học Y Hà Nôi

${ }^{2}$ Bênh viên Đai hoc Y Hà Nôi.

Chịu trách nhiệm chính: Đỗ Văn Minh

Email: mindovan@hmu.edu.vn

Ngày nhận bài: 11.6.2021

Ngày phản biên khoa hoc: 30.7.2021

Ngày duyệt bài: 12.8 .2021
Đỗ Văn Minh ${ }^{1,2}$
SUMMARY

EVALUATION OF PATIENT

COMPREHENSION AND SATISFACTION IN

INFORMED CONSENT FOR ARTHROSCOPIC ANTERIOR CRUCIATE LIGAMENT

RECONSTRUCTION IN HANOI MEDICAL UNIVERSITY HOSPITAL

Objectives: To evaluate the patient comprehension and satisfaction in informed consent for arthroscopic anterior cruciate ligament reconstruction in Hanoi Medical University Hospital. Materials and method: A total 86 patients undergoing arthroscopic anterior cruciate ligament reconstruction were randomized to ask to complete a detailed questionnairethat designed to evaluate the patient comprehension and satisfaction of the informed consent process prior to the operating room in Hanoi Medical University Hospital from June 2019 to December 2020. Results: Doctors provided more information aboutmain diagnosis, anatomical injuries in the knee joint, reason for surgery, doctor's interventions, major complications than information about post- operative feeling, pain and paincontrol, time off work, chances of successful surgery and precautions in daily activities. Almost patients felt normal with informed consent process. Conclusion: The informed consent process for arthroscopic anterior cruciate ligament reconstruction should be done more effectively to make patientan informed decision to surgery and satisfy with its process.

Keyword: informed consent; knee arthroscopy, anterior cruciate ligament reconstruction, Hanoi Medical University Hospital.

\section{I. ĐẶT VẤN ĐỀ}

Đồng thuận dựa trên sự hiểu biết sau khi đã được cung cấp các thông tin cần thiết là một vấn 